\title{
Level of Educational Attainment (LEA) and IQ Indicators: A Case Study Approach
}

\author{
Donovan A. McFarlane
}

Department of Politics and International Relations, Steven J. Green School of International and Public Affairs, Florida International University - Biscayne Campus, 3000 Northeast $151^{\text {st }}$ Street, Miami, FL 33181

dmcfarla@fiu.edu

\begin{abstract}
Keywords: Constitution, Democrats, Intelligence Quotient (IQ), Level of Educational Attainment (LEA), Representative, Republicans, Senator
\end{abstract}

\begin{abstract}
This paper examines the constructs "Level of Educational Attainment" (LEA) and "Intelligence Quotient" (IQ) using a Case Study Approach based in current United States political conflicts and debates between U.S. Representative Maxine Waters and U.S. President Donald Trump. Specifically, the researcher examines U.S. President Donald Trump's claim that U.S. Representative Maxine Waters, a democratic member of the U.S. Congress from the State of California, is a "low IQ individual". The researcher examines IQ indicators and focuses on the Level of Educational Attainment (LEA) of Trump and Waters by accessing, analyzing, and interpreting the most current vital data on Level of Educational Attainment (LEA) at the postsecondary level, specifically examining both parties' (Trump and Waters) LEA in relation to the population samples within their age groups. Additionally, the researcher briefly looks at the life circumstances of both Donald Trump and Maxine Waters to make an educated conclusion about both leaders' levels of intelligence and IQs.
\end{abstract}

\section{Introduction}

The current and $45^{\text {th }}$ President of the United States, Donald J. Trump, is known for his vile language, confrontational tones, mocking and labeling his opponents and political contenders with various names and in ways that are deemed uncivilized, barbaric, and even downright racist by many Americans including ordinary citizens, political and legal scholars, party members from both sides of the isle - Republicans and Democrats, and by non-American observers and viewers, leaders, commentators and people across the globe. This behavior is seen by many as unbecoming for one bearing the title, office, and responsibility of President of the United States, one of the highest offices of leadership, importance, and value in today's world. On the other hand, the President's most fervent advocates and supporters find his rhetoric, characterization, criticisms, and demeaning of others, especially Mexicans, immigrants, previous U.S. presidents including Barack Obama and George H.W. Bush (Bush Senior), and members of both political parties, as well as journalists and news media personalities, among others, as entertaining, funny, newsworthy, and even good policy and great politics.

Two politicians and members of the U.S. government who have more than others incurred the demeaning scorn and disdain of President Trump and his followers are Representative Maxine Waters (D) and Senator Elizabeth Warren (D), and who happen to be two of his most adamant critics and members of Congress who stand up to the President and his questionable behaviors, policies, and decisions as the Congress is meant to do according to its roles, functions, and responsibilities under the U.S. Constitution, republican form of government, and democracy. Maxine Waters is an American politician serving as the U.S. Representative for California's $43^{\text {rd }}$ congressional district (D), while Elizabeth Warren is an American politician and academic serving as the senior United States Senator from Massachusetts (D). President Trump has been decisively and consistently harsh against these two women and governmental colleagues more than any others, often and continually labeling Representative Maxine Waters as a "low IQ individual" and Senator Elizabeth Warren as "Pocahontas". These terms are both seen as insulting, racially motivated, and 
disrespectful when used by any individual toward any other in civil society, and when used by the President of the United States, represent a new kind of low. The fact is that we do not expect our leaders, and especially the President of the United States to be less civil than us ordinary citizens, and this is what makes President Trump's usage of the terms and characterization of these two members of Congress in such ways, reprehensible, unethical, and viler than if uttered by an ordinary citizen.

\section{IQ Labeling: Facts, Findings and Challenges}

When it comes to Representative Maxine Waters (D), President Donald J. Trump insistently labels her a "low IQ" person or individual and his base seems to enjoy this, as well as some otherwise rational and even intelligent individuals across the American landscape who should be able to take a more objective approach to examining the President's characterization by virtue of its truthfulness, validity, and evidence. Maxine Waters is known for her vehement strides against Donald Trump's behaviors and some of his policies, and most if not all of his conduct and behavioral standards. This certainly and obviously makes President Trump furious, hostile, and aggressive against her more than others in his verbal attacks and condemnation. Donald J. Trump, even before becoming President of the United States was known for his biting words, fighting personality, and confrontational behaviors. Thus, it is not surprising how he responds to whom he perceives and views as a strong opponent whom he cannot fire from the job. We have certainly seen that the current President does not hesitate too much in firing even his supporters and subordinates who have been instrumental to his success in the 2016 Presidential Campaign, and those who have worked to defend both himself and his policies in his administration. President Trump cannot fire Representative Maxine Waters, if he would have done so long time ago. Thus, the only response is to demean her and rally his base and support against her in a very Draconian style and manner.

When we examine rationally and objectively, the President's constant labeling of Maxine Waters as a "low IQ" person or individual, we need to look at both their level of educational attainment (LEA) and indicators of their IQ (intelligence quotient) since we have no IQ score for any of these individuals. Furthermore, it is important to note that the reported IQ of President Donald J. Trump being 156 is simply a rumor and not empirical or factual in any form or another. In fact, the claim can be traced by to a 2006 study conducted by Dean Keith Simonton of the University of California-Davis, where a so-called "historiometric" approach or model was used to estimate the IQs of presidents seeing that IQ scores are not available in empirical form for most presidents. Estimating IQs for anyone is as good as guessing the lotto numbers and nothing more since many factors outside of potential modeling can significantly impact and affect one's performance on standardized tests, which have remained the most empirical approach to testing and comparing individual IQs. With that settled, we also have no record of Representative Maxine Waters' IQ known and available to the public. This places both contenders, Donald J. Trump and Maxine Waters on an equal platform when it comes to guessing and guesstimating IQs.

\section{Education and Circumstances of Trump and Waters}

We should examine the individual educational attainment of both Donald Trump and Maxine Waters. Donald Trump attended Fordham University, and then transferred after two years to the Wharton School of the University of Pennsylvania, from which he graduated in 1968 with a Bachelor of Science degree in Economics. Since then Donald Trump has operated various businesses with massive inheritance from his father [1]. Maxine Waters attended Los Angeles State College, which is now California State University, Los Angeles, and graduated in 1972 with a Bachelor of Arts degree in Sociology. Record also indicates that Maxine Waters was an assistant teacher for Head Start, which was a federally funded program for the success of low-income students. Soon after this role, she ventured into politics as early as 1973 and was elected to the California Assembly in 1976 [2]. These are both sufficiently respectable backgrounds to indicate some level of intelligence in both Donald Trump and Maxine Waters. As to the level of intelligence, 
we can only guess. We certainly know this however, Donald Trump had a massive inheritance and the privilege of being a White male in a time where America was more racially divided, and Maxine Waters was simply a Black girl who first began working at age 13 in a racially segregated downtown St. Louis whites-only restaurant. These facts certainly create disparities and challenges in guessing at both personalities' IQs and certainly indicate one thing more than any other - that Maxine Waters is certainly an intelligent woman to have survived from segregated St. Louis up to present as a United States Congresswoman. The circumstances of Donald Trump's life and Maxine Waters' life certainly point to comparable intelligence that necessitated and led to survival up to this point with Maxine Waters perhaps generating great respect as a common person by virtue of background and circumstances from which she has emerged into her position today. Where one person starts out with more than plenty (Donald Trump) and another starts out with very little to nothing (Maxine Waters) and we compare their positions and accomplishments today, we can certainly gain some insights into their intelligence, and by this virtue, Maxine Waters must certainly be an intelligent woman.

\section{Level of Educational Attainment (LEA) Considerations}

Concerning real statistics on level of educational attainment (LEA), we turn to the United States Census Bureau, one of the most authoritative source on educational statistics. The most current statistics on level of educational attainment (LEA) gleaned from data on "Educational Attainment of the Population 18 Years and Over, by Age, Sex, Race, and Hispanic Origin: 2017" (Table 1) should provide some basis for comparing level educational attainment (LEA) of Donald Trump and Maxine Waters. The author has modified or adapted the table by simply deleting the data for elementary, middle, and high schools since we are looking at college-level or postsecondary educational attainment for both Donald Trump and Maxine Waters. 
Table 1. Post-Secondary Educational Attainment of the Population 18 Years and Over, by Age, Sex, Race, and Hispanic Origin: 2017 (Numbers in thousands. Civilians noninstitutionalized population $^{1}$ ).

\begin{tabular}{|c|c|c|c|c|c|c|c|c|}
\hline \multirow[t]{2}{*}{ All Races } & \multicolumn{8}{|c|}{ Educational Attainment } \\
\hline & Total & $\begin{array}{c}\text { Some } \\
\text { college, no } \\
\text { degree }\end{array}$ & $\begin{array}{c}\text { Associate's } \\
\text { degree, } \\
\text { occupational }\end{array}$ & $\begin{array}{c}\text { Associate's } \\
\text { degree, } \\
\text { academic }\end{array}$ & $\begin{array}{c}\text { Bachelor's } \\
\text { degree }\end{array}$ & $\begin{array}{c}\text { Master's } \\
\text { degree }\end{array}$ & $\begin{array}{c}\text { Professional } \\
\text { degree }\end{array}$ & $\begin{array}{c}\text { Doctoral } \\
\text { degree }\end{array}$ \\
\hline Both Sexes & & & & & & & & \\
\hline 18 years and over & 246,325 & 46,445 & 10,081 & 13,990 & 49,368 & 20,797 & 3,196 & 4,096 \\
\hline 18 to 24 years & 29,404 & 10,990 & 672 & 1,088 & 3,105 & 205 & 25 & 20 \\
\hline 25 years and over & 216,921 & 35,455 & 9,408 & 12,902 & 46,262 & 20,592 & 3,172 & 4,077 \\
\hline 25 to 29 years & 22,745 & 4,462 & 918 & 1,463 & 6,028 & 1,675 & 197 & 214 \\
\hline 30 to 34 years & 21,505 & 3,680 & 893 & 1,376 & 5,356 & 2,197 & 357 & 458 \\
\hline 35 to 39 years & 20,773 & 3,209 & 914 & 1,284 & 4,984 & 2,438 & 283 & 434 \\
\hline 40 to 44 years & 19,273 & 2,890 & 941 & 1,197 & 4,622 & 2,273 & 325 & 432 \\
\hline 45 to 49 years & 20,662 & 3,149 & 907 & 1,300 & 4,612 & 2,198 & 323 & 410 \\
\hline 50 to 54 years & 21,364 & 3,338 & 1,020 & 1,473 & 4,247 & 1,937 & 264 & 394 \\
\hline 55 to 59 years & 21,837 & 3,515 & 1,024 & 1,426 & 4,235 & 1,715 & 337 & 353 \\
\hline 60 to 64 years & 19,488 & 3,393 & 892 & 1,196 & 3,658 & 1,859 & 319 & 358 \\
\hline 65 to 69 years & 16,750 & 2,805 & 780 & 875 & 3,295 & 1,707 & 312 & 358 \\
\hline 70 to 74 years & 12,462 & 1,951 & 511 & 577 & 2,308 & 1,247 & 200 & 270 \\
\hline 75 years and over & 20,062 & 3,063 & 609 & 735 & 2,918 & 1,346 & 254 & 396 \\
\hline Male & & & & & & & & \\
\hline 18 years and over & 119,170 & 22,198 & 4,682 & 5,711 & 23,223 & 9,117 & 1,770 & 2,396 \\
\hline 18 to 24 years & 14,845 & 5,268 & 308 & 434 & 1,317 & 68 & 6 & 4 \\
\hline 25 years and over & 104,324 & 16,930 & 4,374 & 5,277 & 21,906 & 9,049 & 1,765 & 2,392 \\
\hline 25 to 29 years & 11,410 & 2,335 & 426 & 631 & 2,765 & 706 & 87 & 98 \\
\hline 30 to 34 years & 10,711 & 1,820 & 412 & 642 & 2,492 & 903 & 190 & 223 \\
\hline 35 to 39 years & 10,281 & 1,564 & 468 & 549 & 2,335 & 935 & 121 & 241 \\
\hline 40 to 44 years & 9,454 & 1,445 & 474 & 502 & 2,134 & 959 & 154 & 232 \\
\hline 45 to 49 years & 10,118 & 1,563 & 409 & 503 & 2,155 & 965 & 142 & 221 \\
\hline 50 to 54 years & 10,449 & 1,550 & 455 & 546 & 1,996 & 878 & 143 & 224 \\
\hline 55 to 59 years & 10,587 & 1,656 & 488 & 552 & 2,004 & 744 & 189 & 215 \\
\hline 60 to 64 years & 9,154 & 1,597 & 437 & 451 & 1,703 & 856 & 193 & 217 \\
\hline 65 to 69 years & 7,907 & 1,255 & 375 & 375 & 1,692 & 812 & 207 & 250 \\
\hline 70 to 74 years & 5,759 & 869 & 184 & 247 & 1,180 & 606 & 164 & 191 \\
\hline 75 years and over & 8,493 & 1,276 & 247 & 280 & 1,450 & 686 & 175 & 279 \\
\hline Female & & & & & & & & \\
\hline 18 years and over & 127,155 & 24,247 & 5,399 & 8,278 & 26,145 & 11,680 & 1,426 & 1,700 \\
\hline 18 to 24 years & 14,559 & 5,721 & 364 & 654 & 1,788 & 137 & 19 & 16 \\
\hline 25 years and over & 112,597 & 18,525 & 5,035 & 7,624 & 24,357 & 11,543 & 1,407 & 1,685 \\
\hline 25 to 29 years & 11,335 & 2,126 & 492 & 832 & 3,264 & 969 & 110 & 116 \\
\hline 30 to 34 years & 10,795 & 1,860 & 481 & 734 & 2,864 & 1,294 & 167 & 235 \\
\hline 35 to 39 years & 10,492 & 1,645 & 447 & 735 & 2,650 & 1,503 & 162 & 192 \\
\hline 40 to 44 years & 9,819 & 1,444 & 467 & 696 & 2,487 & 1,315 & 171 & 200 \\
\hline 45 to 49 years & 10,543 & 1,587 & 498 & 797 & 2,456 & 1,233 & 182 & 189 \\
\hline 50 to 54 years & 10,915 & 1,788 & 565 & 927 & 2,251 & 1,058 & 121 & 170 \\
\hline 55 to 59 years & 11,250 & 1,859 & 536 & 874 & 2,231 & 971 & 148 & 137 \\
\hline 60 to 64 years & 10,334 & 1,796 & 455 & 745 & 1,954 & 1,003 & 126 & 140 \\
\hline 65 to 69 years & 8,843 & 1,550 & 405 & 500 & 1,603 & 895 & 105 & 108 \\
\hline 70 to 74 years & 6,702 & 1,082 & 327 & 330 & 1,128 & 641 & 36 & 79 \\
\hline 75 years and over & 11,569 & 1,788 & 361 & 455 & 1,468 & 660 & 79 & 117 \\
\hline
\end{tabular}

A dash (-) represents zero or rounds to zero.

${ }^{1}$ Plus armed forces living off post or with their families on post.

Source: (Adapted) United States Census Bureau (2017).

Examining Table 1 above, we can see the number of Americans in millions by virtue of their level of post-secondary education to include some college, academic and occupational associate degrees, bachelor's, master's, professional, and doctoral degrees. Our major focus in this particular is the bachelor's degree level of educational attainment (LEA) since both Maxine Waters and Donald Trump hold bachelor's degrees from universities. Some be will tempted to argue that not all bachelor's degrees are equal since Trump's degree is in Economics and Waters' degree is in Sociology, and also since Trump's degree is from the Wharton School of University of Pennsylvania and Waters' degree is from California State University, Los Angeles. Both schools today offer comparable levels of education for argument's sake, and for our purpose and that of the U.S. Census Bureau on educational attainment of the population, a bachelor's degree is a bachelor's 
degree, translated into an undergraduate college or university degree, which is a four-year degree, and a credential above a two-year degree or associate degree. Thus, Trump and Waters have equal level educational attainment (LEA). If this were the sole factor by which their intelligence could be judged, then it could be argued that both have the same level of intelligence and potentially IQ. However, we know that intelligence and IQ are more complex and abstract than any instrument or even a single factor can measure. Thus, we must use what is available empirically to treat both subjects when it comes to IQ indicators.

When it comes to the age-educational attainment related component in Table 1 above, Trump falls into the "70 to 74 years" category, and Waters falls into the " 75 years and over" category. In the "70 to 74 years" category for both sexes in the general population, Trump is among the 2.3 million members of the U.S. population 70 to 74 years old who has attained a Bachelor's degree as of December 2017. When it comes to the "75 years and over" category, Waters is one of the 2.9 million Americans 75 years and over who has attained a Bachelor's degree as of December 2017 [5]. When we examine males in the "70 to 74 years" category, Trump is among the roughly 1.2 million (1.18 million) Americans age 70 to 74 who has attained a Bachelor's degree as of December 2017. When it comes to females in the "75 years and over" category, Waters is among the roughly 1.5 million (1.46 million) Americans who has attained a Bachelor's degree as of December 2017 [5]. This certainly places both of them in the category of having the same level of educational attainment (LEA), and this seems to be the only solidly empirical factor on which we can compare their IQs.

While many will point to the economic and political attainments of both Donald J. Trump and Maxine Waters as indicators of their IQs, this is not objective or empirical in any ways since there are many politically and economically unaccomplished individuals in this country who are super intelligent by any measure and standard. A good example of the flaw in characterizing one's levels of political and economic well-being as indicator of IQs is evidenced when we look at the performance of children and people from extremely economically and financially poor places and backgrounds and compare those to children and people who have had access to wealth and better standards of living. For example, when we observe the Spelling Bee competition or performance of people from poor countries and economically impoverished upbringing in areas of science, mathematics, engineering and the like compared to United States' and British and Canadian citizens, we can see a striking difference, and the difference is not in favor of those from these wealthy and developed nations. Based on these, comparing Trump's wealth and success as an entrepreneur to Waters' is not a good defense or indicator of superior IQ. Thus, the best indicators might be their individual level educational attainment (LEA). Based on the empirical evidence and statistics we have, as well as other facts concerning level of educational attainment (LEA), both Donald Trump and Maxine Waters are intelligent people.

\section{Conclusion and Recommendations}

If we were to use factors such as political accomplishments and experience, Maxine Waters would certainly outrank Donald Trump by virtue of her long tenure in politics and the United States Congress. However, even such factors will not provide much insight into IQs, unless we are examining what can be called "political IQs". President Trump is only recently a politician, and he himself would probably argue that he is not a politician, as he has communicated this in the past. It is interesting that Donald Trump does not label Elizabeth Warren as a "low IQ" person or individual when we consider the fact that it would be rather ridiculous since Warren has higher level of educational attainment (LEA) than Donald Trump. Warren attended George Washington University, and then University of Houston, where she earned a Bachelor of Science degree in Speech Pathology and Audiology, and Rutgers University Law School where she earned a J.D. degree [3]. Warren's highest degree, the J.D., is categorized as a "Professional degree" and places the 69 years old in the category of 312,000 Americans age "65 to 69" with this level of educational attainment (LEA) as of December 2017 (Table 1, [5]). Furthermore, this also places Warren into the category of females " 65 to 69 years" with this level of educational attainment (LEA) of which there 
were 105, 000 in December 2017 [5]. There is suspicion that Trump's labeling of Maxine Waters as a "low IQ" person or individual has much to do with her gender and race as a Black woman, and may also indicate the President's innate predisposition to characterize and subconsciously think of Blacks in general as having low IQs. Trump's labeling and mocking of Senator Warren as "Pocahontas" is not only racially insensitive, but disrespectful to American Indians or Native American heritage and the oppressions they suffered at the hands of Whites in the United States. It is believed that Pocahontas was a Native American woman with strong association to the colonial settlement at Jamestown, Virginia, and who was reportedly captured and held for ransom by the English during Anglo-Indian hostilities in 1613, and was also integrated, seemingly, voluntarily into White society [4].

Regardless of your perspective and ideological and political leanings and affiliations, the fact remains that we look to our leaders, not just the President of the United States, but also to our members of Congress including Waters and Warren for behaviors and examples that can better guide and mold our values to exist and live harmoniously and peacefully in a democracy and civil society. The current childish game of name-calling and use of terms such as "low IQ" and "Pocahontas" to describe political colleagues and opponents is both uncivilized and poisonous and represents political and social bullying which sets a bad example for citizens, and most agonizingly, children and future leaders. Similarly, the call for harassing others in public domain is damaging to peaceful and harmonious relationships in a society already rocked by racial tensions and political differences. The President of the United States, Donald J. Trump, must set a better example for the nation, the rest of the world, members of his party, and for the children who are being exposed to such conduct and behaviors. The members of Congress, including both Representative Maxine Waters and Senator Elizabeth Warren must refrain from responding in like to the President's behaviors and conduct, as they more than the President of the United States, represent democracy and the form of republican government (representatives of the people) than any other members of U.S. government per explicit and implied indications of the U.S. Constitution and its framers.

\section{Conflict of Interest}

The author declares that there is no conflict of interest.

\section{References}

[1] Encyclopedia Britannica. (2017). Donald Trump. Retrieved July 7, 2018, from https://www.britannica.com/biography/Donald-Trump.

[2] T. Gale, (2005). "Waters, Maxine" in Contemporary Black Biography. Retrieved July 07, 2018, from Encyclopedia.com: http://www.encyclopedia.com/education/news-wires-whitepapers-and-books/waters-maxine.

[3] J. Glenn, The Biography of Elizabeth Warren. United States of America: CreateSpace Independent Publishing Platform, 2017.

[4] D. Michals, (2015). Pocahontas. Retrieved July 7, 2018, from https://www.womenshistory.org/education-resources/biographies/pocahontas.

[5] United States Census Bureau, Educational Attainment in the United States: 2017. Retrieved July 7, 2018, from https://www.census.gov/data/tables/2017/demo/education-attainment/cpsdetailed-tables.html. 